\title{
Gratitude With Well Being for Elderly Who Live in Social Care Residence : A Review
}

\author{
Siti Fatimah \\ Faculty of Psychology \\ University of Muhammadiyah Malang \\ alaydrussyarifah@gmail.com
}

\begin{abstract}
The purpose of this article was to review on gratitude with wellbeing for elderly who live in Social Care Residence. The review is based on the goals, demographic aspects, and research design used in the study. The review was 12 studies published on International Journal from 2008-2016. The results of the review indicate that the tendency of subjects who were targeted in the study were elderly with age over 65 years with various psychological conditions. Quantitative was the most research design used in these research, others used experimental and qualitative case study. These trends and their implication for future research, especially at the social care residence that examine gratitude with wellbeing are discussed.
\end{abstract}

Keywords: review, gratitude, wellbeing, elderly.

\section{INTRODUCTION}

Pychological Well-Being on the individual is not only seen as the presence or absence of a mental disorder, but also the individual's consciousness of the positive psychological resources it has (Christopher, 1999: Hupert, 2009; Mooeenizadeeh \& Salagame, 2010). Ryff (1989) adds that psychological wellbeing is a concept related to what the individual perceives about activities in everyday life and leads to the expression of personal feelings for what is felt by the individual as a result of his life experience.

According to Ryff (1989) the description of the characteristics of people with psychological well-being refers to Rogers's view of a fully functioning person, Maslow's view of self-actualization, Jung's view of individuation, Allport's concept of maturity, the concept of Erikson in describing individuals who achieve integration rather than despair Psychological wellbeing can be characterized by the acquisition of happiness, life satisfaction and the absence of signs of depression (Ryff, 1995). Psychological welfare is closely related to a sense of gratitude. The results show that gratitude and forgiveness has been found to be positively correlated with psychological wellbeing and life satisfaction (Shruti Shourie, 2016). The degree of gratitude is more than a personality factor because it is important for a person in obtaining subjective well-being (Chih-Che Lin, 2013).

Gratitude can be expressed because there is a good fortune in the self and the luck does not have to make someone successful or not. According to Wood, Joseph \& Maltby (2009) kebersyukuran as a personal trait of positive thinking, present a more positive life. While McCullough, Emmons, Kilpatrick \& Larson (2001) conceptualize gratitude as a moral feeling, because usually moral feelings can cause concern for others. Being grateful for life experiences has a positive impact on the behavior of individuals. Individuals who can be grateful for their life experiences, whether positive or negative experiences show more positive behavior (McCullough, Tsang \& Emmons, 2004).
Polak \& McCullough (2006) show that gratitude is the recognition that one can benefit from the good of others. McCullough, Kimeldorf \& Cohen (2008) define gratitude as a pleasant emotion, but unlike happiness due to gratitude is usually preceded by the perception that someone has benefited from the good of others, because gratitude is based on receiving benefits from others. The same is true of Froh, Fan, Emmons, Bono, Huebner \& Watkins (2011) that gratitude is an appreciation experienced by individuals when someone does something good or beneficial to them.

The Elderly Period is a period of adjustment to diminished strength and health, looking back on life, retirement and adjustment to social roles (Santrock, 2006). Psychically, the elderly feel anxious to face the end of his life, although there are still many elderly who can bring happiness and grateful for the time of his life. In general kebersyukuran will not be separated from various circumstances that mengiriinya. Kebersyukuran will always be closely related to the acquisition of a favor, but different things when someone is faced with the opposite condition.

McCullough (2002) found that grateful people, compared to their less grateful counterparts, tend to experience more positive emotions, enjoy greater satisfaction with life and more expectations, and tend to experience depression and anxiety. Researchers assume that if the elderly are able to reach a high gratitude point it will be followed by high levels of well-being in themselves. From the above explanation, researchers are interested in discussing the relationship between gratitude and wellbeing in the elderly living in the orphanage.

\section{Review Procedure}

Collection of research results conducted by looking for literature in the form of journal articles via computer on several websites, among others:

1.www.eric.ed.gov

2.www.scholar.google.co.id

3.www.proquest.com

4.www.e-resourches perpustakaanindonesia.com 
The keywords used in the journal literature search are gratitude, wellbeing, life satisfaction, subjective wellbeing, psychological wellbeing, erderly, late adulthood.

\section{REVIEW AND DISCUSSION}

After a review of 12 research journals on gratitude and wellbeing, the following presented a summary of the results study.

\begin{tabular}{|c|c|c|c|c|c|}
\hline No & Peneliti \& Tahun & Subjek & $\mathbf{X}$ & $\mathbf{Y}$ & Hasil \\
\hline 1. & $\begin{array}{l}\text { Loren Toussaint, Philip } \\
\text { Friedman (2009) }\end{array}$ & 72 patient & Gratitude & $\begin{array}{l}\text { Forgiveness } \\
\text { and well being in } \\
\text { mediation by role of } \\
\text { affect and beliefs }\end{array}$ & $\begin{array}{l}\text { There is a positive } \\
\text { relationship between } \\
\text { gratitude with wellbeing and } \\
\text { has a strong relationship } \\
\text { with the mediation factor } \\
\qquad(\mathrm{rxy}=0.59)\end{array}$ \\
\hline 2. & $\begin{array}{l}\text { Lung Hung Chen, } \\
\text { (2008) }\end{array}$ & $\begin{array}{l}\text { Study 1: } 169 \text { high } \\
\text { school athletes } \\
\text { Study 2: } \\
265 \text { adult athletes }\end{array}$ & $\begin{array}{l}\text { Sport } \\
\text { dispositional } \\
\text { gratitude }\end{array}$ & $\begin{array}{l}\text { Team satisfaction } \\
\text { and life satisfaction }\end{array}$ & $\begin{array}{l}\text { There is a positive } \\
\text { relationship between } \\
\text { dispositional gratitude and } \\
\text { life satisfaction } \\
\qquad(\text { rxy }=0.43)\end{array}$ \\
\hline 3. & $\begin{array}{l}\text { Shruti Shourie, } \\
\text { Harsmeet Kaur (2016) }\end{array}$ & $\begin{array}{l}250 \text { students ages } \\
16-18 \text { years }\end{array}$ & $\begin{array}{l}\text { Gratitude, } \\
\text { forgiveness }\end{array}$ & $\begin{array}{l}\text { Psychological } \\
\text { wellbeing }\end{array}$ & $\begin{array}{l}\text { There is a positive } \\
\text { relationship between } \\
\text { Gratitude, forgiveness with } \\
\text { Psychological wellbeing. } \\
\text { (rxy }=0.17 \text { ) }\end{array}$ \\
\hline 4. & Chin-Che Lin, (2013) & 504 students & Gratitude & Subjective wellbeing & $\begin{array}{l}\text { There is a positive } \\
\text { relationship between } \\
\text { Gratitude and Subjective } \\
\text { wellbeing (rxy }=0.37 \text { ) }\end{array}$ \\
\hline 5. & Chih-Che Lin (2015) & 375 students & Gratitude & $\begin{array}{l}\text { Resource } \\
\text { development and } \\
\text { emotional wellbeing }\end{array}$ & $\begin{array}{l}\text { There is a positive } \\
\text { relationship between } \\
\text { Gratitude with social } \\
\text { support, positive emotion, } \\
\text { emotional wellbeing. }\end{array}$ \\
\hline 6. & $\begin{array}{l}\text { Brenna D.Hoy, Shannon } \\
\text { M.Suldo (2013) }\end{array}$ & $\begin{array}{l}148 \text { elementary } \\
\text { school students }\end{array}$ & $\begin{array}{l}\text { Parents and } \\
\text { children's } \\
\text { gratitude }\end{array}$ & $\begin{array}{l}\text { Life satisfaction and } \\
\text { hope }\end{array}$ & $\begin{array}{l}\text { There is a positive } \\
\text { relationship between child } \\
\text { satisfaction with parents } \\
\text { satisfaction ( } \mathrm{rxy}=0.26) \text {. }\end{array}$ \\
\hline 7. & $\begin{array}{l}\text { Yu-Chu Yeh, Chih-Che } \\
\text { Lin (2014) }\end{array}$ & 750 students & Gratitude & wellbeing & $\begin{array}{l}\text { There is a positive } \\
\text { relationship between } \\
\text { Gratitude with wellbeing } \\
(\text { rxy }=0.43)\end{array}$ \\
\hline 8. & Peizhen Sun (2013) & $\begin{array}{l}354 \text { final-year } \\
\text { students }\end{array}$ & Gratitude & Life satisfaction & $\begin{array}{l}\text { There is a positive } \\
\text { relationship between } \\
\text { gratitude and life } \\
\text { satisfaction mediated with } \\
\text { affective (rxy }=0.95 \text { ) }\end{array}$ \\
\hline 9. & $\begin{array}{l}\text { Philip C.Watkins, } \\
\text { Russel Kolts(2003) }\end{array}$ & $\begin{array}{l}237 \text { Psychology } \\
\text { student }\end{array}$ & $\begin{array}{l}\text { Gratitude and } \\
\text { happiness }\end{array}$ & Subjective wellbeing & $\begin{array}{l}\text { The gratitude scale has good } \\
\text { internal consistency against } \\
\text { subjective wellbeing. }\end{array}$ \\
\hline 10. & $\begin{array}{l}\text { Carmel Proctor, John } \\
\text { Maltaby (2010) }\end{array}$ & $\begin{array}{l}135 \\
\text { Psychology } \\
\text { student }\end{array}$ & Strength & $\begin{array}{l}\text { Well being and } \\
\text { health related quality } \\
\text { of life }\end{array}$ & $\begin{array}{l}\text { There is a positive } \\
\text { relationship between } \\
\text { strength with subjective } \\
\text { wellbeing ( } \mathrm{rxy}=0.15 \text { ) }\end{array}$ \\
\hline 11. & Allison Killen(2015) & 88 elderly & $\begin{array}{l}\text { Gratitude } \\
\text { intervention }\end{array}$ & wellbeing & $\begin{array}{l}\text { Gratitude interventions have } \\
\text { great benefits for improving } \\
\text { well being for the elderly. }\end{array}$ \\
\hline 12. & Elliot Kruse (2014) & $\begin{array}{l}50 \text { the final adult } \\
\text { participant }\end{array}$ & Gratitude & Humility & $\begin{array}{l}\text { Gratitude has a positive } \\
\text { relationship with humility } \\
(\mathrm{rxy}=0.38)\end{array}$ \\
\hline
\end{tabular}




\section{REFERENCE}

Alison Killen, Ann Macaskill, (2014). Using a Gratitude Intervention to Enhance Well-Being in Older Adults.

Brenna D. Hoy, Shannon M. Suldo, Linda Raffaele Mendez. (2012). Links Between Parents' and Children's Levels of Gratitude, Life Satisfaction, and Hope.

Carmel Proctor, John Maltby, P. Alex Linley (2010).Strengths Use as a Predictor of Well-Being and Health-Related Quality of Life.

Caroline R. Lavelock, Brandon J. Griffin, Everett L. Worthington, Jr., Eric G. Benotsch. (2016). Qualitative Review and Integrative Model of Gratitude and Physical Health.2016, Vol. 44, No. 1, 55-86.

Chih-Che Lin, (2013). A higher-Order Gratitude Uniquely Predicts Subjective Well-Being: Incremental Validity Above the Personality and a Single Gratitude.

CHIH-CHE LIN, (2015). Impact Of Gratitude On Resource Development and Emotional Well-Being.

Elliot Kruse, Jhoseph Chancellor et al., (2014). An Upward Spiral Between Gratitude and Humility.

Jeffrey J. Froh - Giacomo Bono - Robert Emmons. (2010). Being grateful is beyond good manners: Gratitude and motivation to contribute to society among early adolescents.

Loren Toussaint and Philip Friedman, (2008). Forgiveness, Gratitude, and Well-Being: The Mediating Role of Affect and Beliefs.
Lung Hung Chen. (2008). Gratitude and Adolescent Athletes' Well-Being. Soc Indic Res (2008) 89:361373.

McCullough, M.E., Emmons, R.A., \& Tsang, J. (2002). The grateful disposition: A conceptualand empirical topography. Journal of Personality and Social Psychology, 82, 112-127.

Michael Argyle and Peter Hills. Oxford Happiness Questionnaire. Oxford University.

Peizhen Sun, Feng Kong, (2013). Affective Mediators of the Influence of Gratitude on Life Satisfaction in Late Adolescence.

Philip C. Watkins, Kathrane Woodward, (2003). Gratitude and Happiness: Development of a measure of Gratitude, and Relationship with Subjective Well Being.

Rachel C. Garthe, Jennifer A. Coleman, and Chelsea M. Hughes, (2016). A Qualitative Review and Integrative Model of Gratitude and Physical Health.

Robert A. Emmons, Michael E. McCullough, (2013)Highlights from the Research Project on Gratitude and Thankfulness.

Santrock, (2003).Adolescence perkembangan remaja. Jakarta. Erlangga.

Shruti Shourie, Harshmeet Kaur, (2016). Gratitude and Forgiveness as Correlates Of Well-Being Among Adolescents.

Snyder, S. R \& Lopez, S. J. (2005). Handbook of Positive Psychology. Oxford University Press.

Yu-chu Yeh,Chih-Che Lin.(2013). How Gratitude Influences Well-Being: A Structural Equation Modeling Approach. Springer Science+Business Media Dordrecht. 